\section{NOTE ON THE}

USE OF SALICYLIC SILK AS A DRESSING FOR WOUNDS, WITH CASES.

BY J. LOCKHART GIBSON, M.B., C.M., RESIDENT PHYSICIAN, EDINBURGE ROYAL INFIRMARY; PRESIDENT OF THE ROYAL MEDICAL SOCIETY, EDINBURGH.

LAST winter I acted as Mr. Chiene's house-surgeon in the Edinburgh Royal Infirmary, and I have received his permission to publish the results we obtained under the use of salicylic silk between the deep and superficial layers of gauze in an antizeptic dressing. What led to the use of salicylic silk was the note of the results obtained in the Leeds Infirmary, published by Mr. Henry Brown in your number of Oct. 8th, 1881. Mr. Chiene did not, however, adopt the Leeds method in its entirety, but, as we think, improved upon it, and so brought out some of the chief advantages of the silk as an addition to an antiseptic gauze dressing.

Our method differed from that used at Leeds in this essential-viz, in the use of no mackintosh. Next the wound was placed a piece of protective of as small a size as possible, and often perforated, as it was used merely to prevent the dressing from sticking to the wound; then two or three layers of carbolic gauze wrung out of 1 to 40 carbolic lotion; above that a variable quatity of salicylic silk; and over all a large dressing of eight plies of carboic gauze. The large dressing we used to protect the silk, which was looked upun as an aseptic though not autiseptic reservoir, and therefore required an auti-eptic covering to prevent it from going wrong when moistened with discharge. It was not thought uecessary to soak the deep dressing in a stronger solution of carbolic acid than the usual 1 to 40 . The mackintosh was dispenved with because the use of the beautifully absorbent silk gave us the means of employing what Mr. Chiene had been long aiming at-viz, a dry dreasing. The advantages found in the silk were-dryness of our wounds, lessening of discharge, diminution of labour to the surgeon, and cheapness. The absence of the maclintosh allowed the fluid part of the discharge to evaporate, and the dressings, when removed, sometımes not till two or three weeks after their first application, were found to be acting the part of a huge scab and to be covering a healed wound. The discharge was lessened because the poulticing action due to the mackintosh was absent. Our wounds in almost every case were drained with chromic catgut, that dressing might not be necessitated for the removal of a drainage-tube. Horsehair stitches were employed, as being more rigid than catgut; as keeping the lips of a wound in more perfect coaptation, and as being easily removed after a wound is healed.

Cases Treated by Salucylic Silk in the Antiseptic Dressing.

\begin{tabular}{|c|c|c|c|}
\hline No. & Nature of case. & $\begin{array}{l}\text { No. of } \\
\text { dressings. }\end{array}$ & $\begin{array}{l}\text { Highest } \\
\text { temperature. }\end{array}$ \\
\hline 1 & Scirrhus of mamma and axillary & 1 & $992^{\circ}$ \\
\hline 2 & $\begin{array}{l}\text { glands. } \\
\text { Scrrrbus of mamma and axillary } \\
\text { glands. }\end{array}$ & 4 & $100 \cdot 8^{\circ}$ \\
\hline 3 & $\begin{array}{l}\text { Trephining for compound de- } \\
\text { pressed (punctured) fracture } \\
\text { of skull. }\end{array}$ & 1 & $99^{\circ}$ after 1st \\
\hline 4 & $\begin{array}{l}\text { Railway injury reflecting the } \\
\text { scalp from nearly the whole } \\
\text { of one side of the head, and } \\
\text { baring and scratching the bone } \\
\text { for an area of two inches in } \\
\text { diameter. }\end{array}$ & 1 & \\
\hline 5 & $\begin{array}{l}\text { Amputation through the middle } \\
\text { of thigh, for cario-necrosis. }\end{array}$ & 4 & $99^{\circ}$ \\
\hline 6 & $\begin{array}{l}\text { Five wounds of vertex, three } \\
\text { penetrating to the bone, and } \\
\text { one exposing a fissured frac- } \\
\text { ture. }\end{array}$ & 1 & $99^{\circ}$ \\
\hline$i$ & $\begin{array}{l}\text { Primary amputation below the } \\
\text { shoulder. }\end{array}$ & 5 & $99 \cdot 8^{\circ}$ \\
\hline 8 & $\begin{array}{l}\text { Syme's amputation at the ankle } \\
\text { (primary). }\end{array}$ & $\begin{array}{c}10 \\
(3 \text { for dis- } \\
\text { charge) }\end{array}$ & $100^{\circ}$ \\
\hline 9 & $\begin{array}{l}\text { Compound fracture of tibia and } \\
\text { fracture of fibula. }\end{array}$ & & $99^{\circ}$ \\
\hline 10 & Compound fracture of tibia. & 3 & $100^{\circ}$ \\
\hline 11 & $\begin{array}{l}\text { Compund fracture of tibia and } \\
\text { fibula, and compound disloca. } \\
\text { tion of the ankle. }\end{array}$ & 12 & $101^{\circ}$ \\
\hline 12 & $\begin{array}{l}\text { Primary amputation of middle } \\
\text { and index fingers, with por- } \\
\text { tions of their metacarpal bones. }\end{array}$ & 3 & $99^{\circ}$ \\
\hline
\end{tabular}

ON A CASE OF MALIGNANT CHOLERA. BY J. EDWIN COONEY, L.F.P.S.G., \&c.

MRS. C_- of Poplar, E., aged fifty-two, of spare habit, after three days of premonitory diarrhoea, during which period she dosed herself from a neighbouring draggist's to no effect, sent for me on June 21st, 1882. Arriving at 8 A.M. I found her shrieking and groaning, tortured by spasms of the carpo-pedal extremities, \&c., which were purple; the countenance had assumed the "facies choleritica," the eye being deeply sunken, red and injected, a broad and livid band encircling the lower part of the orbit; every feature was sharp and pinched, the complexion thick and muddy, and the lips and tongue purple. The whole body was bathed in a cold and clammy sweat; the voice scarcely audible. Temperature (external) was below $95^{\circ} \mathrm{F}$.; pulse not appre-
Dressed on the operating-table. Dressing removed on the fifteenth day. Wound found healed.

Only once dressed for discharge (oozing); twice for drainage-tube in axilla, which had been used because some glands surrounding the axillary vessols, and, therefore, not removed, had been touched with axillary vessels, and, therefore, not removed, had been touched with chloride of zinc. Drainage

Bone, to the size of a crown-piece, removed from vertex. Dressing Bone, to the size of a crown-piece, removed from vertex. Dressing
removed on the fifteenth day. Wound found healed. Dismissed a removed on the ifteenth

Dressed on the eleventh day, and found healed.

Healed on the seventeenth day. Dressed on the first, fourth, tenth, and seventeenth days.

Dressed on the twelfth day, and found healed.

Drainage-tube used because flaps were doubtful. Only two of the dressings were necessitated by discharge.

The frequent dressings were necessary for the watching of a linear slough of the beel-flap, which had been injured by the accident. The case was in for eight weeks. Very good stump.

Dressing removed in twenty-one days. Wound found to be quite superficial, with distinct union of bones. In another fortnight the wound healed, and patient was dismissed.

The patient (a woman) had fracture of the true pelvis and of a rib, in addition to the tibial injury. Dismissed in six weeks.

The cas to the tibial injary. Dise of the thix pelsis and of a rib, in the wound healed and a movable ankle. The last five dressings were not necessitated by discharge. Healed on the twelf th day. ciable in wrists and superficial arteries. Ooe of the heart's sounds only detected. Vomiting and purging incessant. She was passing painless motions of the true choleraic characterviz., copious white flocculi suspended in a watery fluid; urine was entirely suppressed since 4 A.M. She was, moreover, extremely restless and tossing about. In other words, she was in the algide state of malignant cholera. At 8 A.M. ice was given ad lib. to suck, also twenty grains of chloral hydrate, with twenty minims of dilute sulphuric acid in a little ice-water, which was rejected. This repeated at 8.30 A.M. was again vomited. At 9 A.M. I gave her a dose of chloral alone (twenty grains), which was retained; and up to 6 P.M. I gave ten grains of chloral every half-hour. Vomiting occurred occasionally in the intervals, but the drug was never rejected. At $10 \mathrm{~A}$.M. I found the bladder empty on passing a catheter, and resolved to inject a pint of tepid water in it to procure its absorution. The symptoms were still urgent, though the sweating and rest. lessness had ceased, and the cramps were shorter in dura. tion and further between. At noon, on passing the 
catheter to carry out my resolution, I found a fluid ounce of urine in the bladder after eight bours' suppression. By 3 P.M. the thermometer marked $96^{\circ} \mathrm{F}$, and at 6 P.M., after toking 180 grains of chloral in nine hours, I noted the external temperature at $962^{\circ} \mathrm{F}$; the pulse was coming back, and the muscular spasms had disappeared, and she had vomited five times; her motions were of the - same character as before, but less frequent, and shortiy before 6 P.M. she expelled a little urine with an alvine evacuation. From 6 P.M. to 6 A.M. the following molning she had five grains of chloral every half-hour, with the exception of two bour's interval during the middle of the night, when the symptoms were observed to become more urgent and the temperature fell below $95^{\circ} \mathrm{F}$. She had a teaspoonful of beef-tea, iced, every half-hour. Chloral, 100 grains.

June 22nd, 1882, 6 A.M.: Temperature $964^{\circ}$; eight stools suring night, when urine was passed; during the day five grains of chloral every half hour $=120$ grains of chloral. 6 P.M.: Temperature $97^{\circ}$; pulse 120 ; vomited twice; ten stools; both heart sounds heard; face and extremities still cyanosed; tive grains of chloral every hour through the night $=$ sixty grains of chloral.-23rd: Temperature $97^{\circ}$; pulse 110; respiration laboured, and 35 a minute; thick purulent sputum brought up frequently (patient states "she usually suffers from chronic bronchitis, and that there is consumption in the family"); coughs for the first time since illness; sbe is very drowsy, and complains of pains in the head; bowels opened eight times through the night, and stained with bile; five grains of chloral hourly, with dilute sulphuric acid=sixty grains of chloral. 6 P.M.: Temperature $97.8^{\circ}$; pu!se 100 ; respiration 24 ; sputum less; two grains and a half of chloral hourly, with acid = thirty grains of chloral.-24tb, 6 A.M.: Temperature $978^{\circ}$; pulse 96; cyanosed appearance almost gone; bowels moved six times through the night, and of a better consistence. The patient is still very drowsy, and has to be roused for nourishment; milk and beef-tea ordered. 6 P.M.: Four stools; temperature $98^{\circ}$; still drowsy; ordered cold to head, and one drachm of brandy every two hours, with nourishment as before; no chloral given this day. $-25 \mathrm{th}, 6$ A.M.: Temperature $978^{\circ}$; purged three times; not so drowsy; no stimulan ts or medicine. 26th: Temperature normal; no relapse or reactionary fever.

Remarlis.-This case has many points of interest to one who has seen much of cholera, but through want of space I will simply allude to a few. There are nnly six cases on record in this country with a premonitory diarrhcea of three days duration, and this is another. Bosides, it is the only case in which suppression of urine lasted only eight hours, the other shortest period being ten hours. Hydrate of chloral was given to an alarming extent-i.e., 180 urains in the first nine hours, and a total of 550 grains or one ounce and a quarter in three days. Though the freshest drug by Liebreich was used, all the usual effects of Jarge doses were not observed, and it is questionable whether the subsequent drowsiness was due to chloral or a ratural sequence of the disease. Further corroborative evidence is necessary to prove whether chloral, besides checking sweating (as in phthisis) and preventing vomiting (as in sea-sickness), has any action ou the kidney secretion, similar to nitrite of amyl. Probably such toleration of larger doses of chloral is due to the loss of the inorganic blood salts by transuration of blood serum via intestinal canal. The early cerstition of the romiting precluded the employment of chloral hypodermically. The administration of the drug was thorough, and the case assiduously watched throughout conjointly hy $\mathrm{Mr}$. G. Elwardes, a Calcutta colleague, and myself. Other medical nen also saw the case. It would be interesting to know what quantity of chloral given hypodermically is equal to a given quantity given by mouth. The early appearance of the urinary secretion prevented my putting into practice my plan of injecting the urinary bladder with water, which oniginated with me, and is not generally Lnown, and which I communicated to THE LANCET with cases some time ago. As the patient and her friends ohjected to my naking internal thermometric ohsorvations (per ragina or rectum) I am unable to produce them.

London.

THE Royal Commission on Metropolitan Sewage Discharge met on 'Tuesday, at 20, Great George-street. Present-Lord Bramwell, in the chair; Sir John Coode, Prof. A. W. Williamson, Dr. De Chaumont, Dr. Thomas Stevenson, Mir. James Abernethy, and Dr. W. Pole (secretary).

\section{NERVE-STRETCHING FOR SUPRA-ORBITAL NEURALGIA,}

WITH REMARKS ON NERVE STRETCHINGS AND THEIR BEARING ON THE MODE OF TRANSMISSION OF NERVE IMPULSES.

By AUGUSTUS H. BAMPTON, M.D., M.CH., ASSISTANT-PHYSICIAN TO THE PLYMOUTh PUBLIC DISPENSARY, ETC.]

ELISHA S- aged sixty-nine, a farm labourer, was admitted to the South Devon and East Cornwall Hospital at Plymouth on March 7th, 1880, suffering from what has been termed epileptiform neuralgia affecting the frontal branches of the first division of the fifth. He had had these attacks of pain off and on for about eighteen months, and the severity had increased so that for the last three weeks he had taken to bis bed.

His family history was good, being the father of ten children, nine of whom were still living. There was no nervous or rheumatic history, and nothing remarkable about his general condition, except that he complained of pain across his chest and shortness of breatb, accounted for by dyspepsia and the age of the tissues. The pain was con. fined to the right side, and was nust intense over the orbit. The right pupil was widely dilated with profuse larrymation. The skin was byperzesthetic, so that a touch would bring on a spasm of pain, and a shade had to be worn over the eye to prevent the impression of light inducing a spasm ; the pain was excruciating, rendering life a hurden. He was ordered a pill of quinine and iron and a belladonna liniment, subsequently aleered to aconite liniment aud phosphorus pill, and the application of the continued current ov $r$ the painful spot. Under this treatment he improved somewhat, the phosphorus being increased to one-fifih of a grain daily, and he relapsed when the battery had to be sent away for repair. At this time be had about forty paroxysms of pain a day. To relieve this nitrite of amyl inhalation was given with some benefit, temporary ouly; so that on June 23rd, at Dr. Clay's request, under whose care he was, Mr. W. Square cut down on the supra-orbital branch of the frontal nerve, and stretched it with a blunt hook, just behind its entrance to the supra. orbital notch, without much difficulty, with the immediate result of cessation of pain. The wound healed by first in. tention, leaviug no perceptible scar, and up to July 19th, the date of his discharge, he had only a slight pricking pain at the outer angle of the eye. In the way of drugs he had lately been taking the saccharated carbonate of iron and codliver oil ; so that here we had almost complete relief from pain following a most simple operation, after a patient trial of many remedies, in so painful a disorder that Trousseau declared be had not seen in his experience ever radically cured by any means.

For neuralgias of an epileptifrom character nerve-section was the last resonrce up to 1869 , when Nosshaum accidentally disenvered the efficacy of nerve-stretching, a procedure which has been carried out some fif $y$ or sixty times in the last few years, in the majority of cases with permanent benefit. In tetanus nerve-stretehing has been employed, but I am not aware with any constarst measure of success. Although in locomotor ataxy the relief by neive-stretching as regards pain and improvement in other symptoms has been well ascertained, and was admitted on all sides at the discussion on the subject at the International Medical Congress, and Professor Morgan, of Manchester, mentioned a case of idiopathic lateral sulerosis, where stret,hing of the left seiatic gave considerable relief as regards pain in both limbs, and temporary disappearance of ankle clonus on the side operated on. The difficulty is to find a satisfactory explanation for the effects of the operation. How is it brought about in such cases? It is geverally considered a sufficient answer in regard to neural ias of inflammatory origin, where adhesions have taken place, that it is the breaking down of such adhesions that effects the cure; but what is the mode of action where other conditions obtain? Professor Eul-nberg believed that it consi-ted in a deficiency of centripetal conduction being brought about. If so, it would be useful only in those nerve lesions of a local character where lesions in nerve centres were of a secondary character. The mode of transmission of nerve impulses is involved in the solution of the ques. 